KS. JERZY ADAMCZYK* - RADOM

\title{
KANONICZNA INSTYTUCJA MUZEUM KOŚCIELNEGO
}

\section{Wstęp}

Papież Jan Paweł II w adhortacji apostolskiej Ecclesia in Europa pisze: „nie można też zapomnieć o pozytywnym zjawisku, jakim jest dowartościowanie kościelnych dóbr kultury. Mogą one bowiem stanowić szczególny bodziec nowego rozwoju humanizmu o inspiracji chrześcijańskiej. Odpowiednio zachowane i roztropnie użytkowane mogą one - jako żywe świadectwo wyznawanej przez wieki wiary - stanowić wartościowe narzędzie nowej ewangelizacji i katechezy, i pobudzać do odkrywania na nowo sensu tajemnicy"1.

Obecność wspólnot chrześcijańskich w wielu kulturach na świecie umożliwia powstawanie dóbr artystycznych, które wraz z upływem czasu nabywają wartości historycznej. Przemiany kulturowe, społeczne i liturgiczne prowadzą do wyłączenia z użytku wielu przedmiotów i dlatego powstaje konieczność właściwego ich przechowywania i konserwowania, aby przekazać przyszłym pokoleniom świadectwo o procesach inkulturacji wiary oraz umożliwić ich oglądanie w muzeach lub innych odpowiednich miejscach ${ }^{2}$.

* Ks. Jerzy Adamczyk - dr hab. prawa kanonicznego, prof. Instytutu Teologicznego UKSW w Radomiu, e-mail: ksjerzyad@wp.pl

${ }^{1}$ Joannes Paulus P.P. II, Adhortatio Apostolica Post-Synodalis Ecclesia in Europa (28 Iunii 2003), nr 60, „Acta Apostolicae Sedis”, 95 (2003) s. 649-719, tekst polski: „L'Osservatore Romano” wydanie polskie, 24 (2003) nr 7-8, s. 4-39.

${ }^{2}$ Por. Pontificia Commissione per i Beni Culturali della Chiesa, Presentatione della Pontificia Commissione, Città del Vaticano 2004, nr 3.5, tekst polski: Prezentacja Papieskiej Komisji do spraw Kościelnych Dóbr Kultury, „Biuletyn kościelnych dóbr kultury”, 1 (2005) s. 92-120; por. Joannes Paulus P.P. II, Constitutio Apostolica Pastor Bonus (dalej: PB), (28 iulii 1988), art. 100, „Acta Apostolicae Sedis", 80 (1988) s. 841-912,; zob. kan. 1234 § 2; por. C. Chenis, Natura, kompetencje, organizacja i działalność Papieskiej Komisji ds. Kościelnych Dóbr Kultury, „Biuletyn Kościelnych Dóbr Kultury", 1 (2005) s. 38; por. W. Partyka, Funkcja duszpasterska muzeum archidiecezjalnego im. bt. Józefa Sebastiana Pelczara, biskupa w Przemyślu, „Archiwa, Biblioteki i Muzea Kościelne”, 79 (2003) s. 140; por. B. Skrzydlewska, Historia i funkcjonowanie muzeów kościelnych, „Archiwa, Biblioteki i Muzea Kościelne” 79 (2003) s. 185. 
„Kościół będąc zarówno widzialnym zgromadzeniem, jak i wspólnotą duchową, kroczy wraz z całą ludzkością tą samą drogą i wraz ze światem doświadcza tego samego losu ziemskiego, a także jest jakby zaczynem i jak gdyby duszą społeczności ludzkiej, która ma być odnowiona w Chrystusie i przekształcona w rodzinę Bożą"3. Jako instytucja Kościół potwierdza przyrodzone, niezależne od władzy świeckiej prawo do nabywania, posiadania, administrowania i zbywania dóbr doczesnych dla osiągnięcia celów, które są mu właściwe ${ }^{4}$.

Do dóbr doczesnych Kościoła należą wszystkie dobra nieruchome i ruchome, a także kosztowności należące do dóbr kultury. W środowisku kościelnym pojęcie dobra kultury zawiera w sobie pojęcie dziedzictwa historyczno-artystycznego, będącego w służbie misji Kościoła 5 .

Tak więc patrimonium historyczno-artystyczne Kościoła posiada wymiar prawny i konsekwentnie muzea kościelne, w których przechowuje się, konserwuje i udostępnia dobra kultury dla publicznego oglądania są instytucjami kanonicznymi ${ }^{6}$.

Przedmiotem niniejszego przedłożenia będzie zagadnienie kanonicznej instytucji muzeów kościelnych. Najpierw uwaga zostanie zwrócona na sprawę pojęcia, celów i rodzajów muzeów kościelnych, z kolei zostanie naświetlona problematyka ustanawiania muzeów kościelnych, potem wyeksplikuje się kwestię organizacji muzeów kościelnych, by wreszcie omówić zagadnienie pracowników tych instytucji oraz ich formacji.

\section{Pojęcie, cele i rodzaje muzeów kościelnych}

Według Słownika wyrazów obcych muzeum to „instytucja gromadząca, przechowująca i konserwująca zbiory z różnych dziedzin kultury, sztuki, nauki i techniki i udostępniająca je publiczności w formie wystaw stałych, czasowych lub objazdowych”, jak również „lokal, budynek mieszczący taką instytucję i zbiory”’

${ }^{3}$ Concilium Oecumenicum Vaticanum II, Constitutio pastoralis de Ecclesia in mundo huius temporis Gaudium et spes (7 Decembris 1965), nr 40, „Acta Apostolicae Sedis”, 58 (1966) s. 10251115, tekst polski: Sobór Watykański II, Konstytucja duszpasterska o Kościele w świecie wspótczesnym Gaudium et spes, w: Sobór Watykański II. Konstytucje, dekrety, deklaracje. Tekst polski. Nowe thumaczenie, Poznań 2002, s. 526-606.

${ }^{4}$ Por. kan. $1254 \S 1$.

${ }^{5}$ Por. Chenis, Natura, kompetencje, s. 22.

${ }^{6}$ Ze Statutu Muzeum Diecezjalnego uchwalonego przez Konferencję Episkopatu Polski dowiadujemy się, że: podstawę prawną istnienia Muzeum Diecezjalnego stanowią: Kodeks Prawa Kanonicznego, Konstytucja o Świętej Liturgii Soboru Watykańskiego II, Okólnik Kongregacji do Spraw Duchowieństwa: W trosce o zachowanie artystycznego i historycznego dziedzictwa Kościoła z dnia 11 kwietnia 1971 r., oraz Normy postępowania w sprawach sztuki kościelnej, uchwalone przez Konferencję Episkopatu Polski dnia 25 stycznia 1973 r.”. Statut Muzeum Diecezjalnego uchwalony przez Konferencję Episkopatu Polski (18 listopada 1976), nr 6, „Currenda”, 127 (1977) nr 5-8, s. 169-170; por. B. Skrzydlewska, Ochrona zabytków sztuki na podstawie dokumentów kościelnych, „Archiwa, Biblioteki i Muzea Kościelne”, 67 (1997) s. 39.

${ }^{7}$ Stownik wyrazów obcych. Wydanie nowe, red. E. Sobol, Warszawa 1991, s. 752. 
Z kolei Mały słownik terminów plastycznych określa muzeum, jako „instytucję mającą na celu zbieranie, ochronę przed zniszczeniem i odpowiednie eksponowanie przedmiotów z różnych dziedzin $\mathrm{m}$. in. sztuki"s.

U źródeł każdego muzeum kościelnego znajdują się bez wątpienia praktyczne motywy ochrony, konserwacji i dowartościowania dziedzictwa artystycznego i kulturowego, będącego własnością Kościoła. W muzeum kościelnym zbiera się rękodzieła o różnej naturze i jakości estetycznej, pochodzące z kościołów i innych miejsc, w których - z różnych przyczyn - nie mogą już one spełniać swej pierwotnej funkcji kulturalnej lub liturgicznej i nie da się ich konserwować i dowartościować. Są to przedmioty, którymi - ze względu na ich ścisły związek z historią kultury - jest zainteresowane samo społeczeństwo, określając je jako dobra kultury czyli dobra, w których „się uznaje wartość cywilizacji”. Nad nimi właśnie muzeum kościelne rozciąga swą opiekę, patronując ich zbieraniu, restaurowaniu, ochronie, konserwacji, naukowemu opracowywaniu i dowartościowaniu.

Jako instytucja zajmująca się materialnymi dobrami kulturowymi, muzeum kościelne nie różni się zatem od zwykłych muzeów. Jego osobliwość wypływa jednak z faktu, że otacza ono troską szczególny rodzaj dóbr kulturowych, to jest religijny. Muzeum kościelne bowiem, zajmując się wyłącznie religijnymi dobrami kulturowymi, przywraca właściwą im wartość, uwypuklając przede wszystkim ich rolę konkretnego świadectwa dawnej religijności wierzących. Obecne w dziele muzealnym ewentualne walory estetyczne, znaki rozpoznawcze artystów, znaczenia związane z ewolucją stylów, które stanowią ważne założenia w organizowaniu zwykłych muzeów historyczno-artystycznych, bądź też znaczenia antropologiczne, socjologiczne i etnograficzne, akcentowane w różnych muzeach kultury, w muzeum diecezjalnym schodzą na dalszy plan. Tutaj uwypukla się przede wszystkim znaczenia ikonologiczne i liturgiczne, funkcje pełnione w świętym rycie, tradycje kulturalne itd. Tak więc figury, obrazy, wyroby ze złota, miniatury, wyposażenia sakralne, wszystko to traktuje się i dowartościowuje jako wyraz życia kościelnego, liturgicznego i duszpasterskiego, pobożności ludowej czy też treści wiary przeżywanej w różnorodnych ujęciach rzeczywistości eklezjalnej9. Tak więc muzeum kościelne należy do kategorii muzeów religijnych mając rację istnienia w kontekście (środowisku) kościelnym.

Według Beaty Skrzydlewskiej, „muzeum religijne to instytucja tworzona w celu gromadzenia, zabezpieczenia przed zniszczeniem i zapewnienia fachowej konserwacji oraz prezentacji obiektów sakralnych (nieużywanych w kulcie)". Autorka dodaje, że muzea religijne najczęściej występują w obrębie kultury chrześcijańskiej ${ }^{10}$. Stąd wniosek, że muzeum religijne może istnieć nie tylko w Kościele katolickim, ale i w kulturze innych wyznań chrześcijańskich, jak również religiach pozachrześcijańskich. W świetle tego muzeum kościelne jawi się jako szczególny rodzaj muzeum religijnego, będącego własnością Kościoła katolickiego.

${ }^{8}$ Mały stownik terminów plastycznych, red. K. Zwolińska, Z. Malicki, Warszawa 1990, s. 192.

${ }^{9}$ Por. G. Menis, Muzea Kościoła, „Communio”, wersja polska, 16 (1996) z. 6, s. 89-90; por. kan. $1220 \S 2$.

${ }^{10}$ B. Skrzydlewska, Muzea religijne, w: Encyklopedia katolicka, t. 13, red. E. Gigilewicz, Lublin 2009, kol. 539. 
Powstaje jednak pytanie: czym jest muzeum kościelne jako instytucja kanoniczna ${ }^{11}$ ? Wydaje się, że korzystając z przywołanej definicji zaproponowanej przez B. Skrzydlewską, jak również z kanonicznej definicji biblioteki kościelnej ${ }^{12}$ oraz z kan. $1254 \S 1^{13}$ można powiedzieć, że muzeum kościelne to instytucja utworzona w celu gromadzenia, zabezpieczenia przed zniszczeniem i zapewnienia fachowej konserwacji oraz prezentacji obiektów sakralnych (nieużywanych w kulcie), dla realizacji celów Kościoła, będąca w posiadaniu instytucji aprobowanych albo erygowanych w systemie kanonicznym ${ }^{14}$.

Rozpatrując zagadnienie celów muzeów kościelnych, należy zaznaczyć, że „są one powiązane z sensus Ecclesiae, który widzi w historii Kościoła stopniowe spełnianie się ludu Bożego"15.

Muzea kościelne mają za cel przede wszystkim ochronę pamięci historycznej. W ramach tego różne zadania: przechowują rękodzieła, gdyż gromadzą wszystkie obiekty, które z powodu trudności dozoru, niewiadomego pochodzenia, alienacji albo zniszczenia struktur przynależności, degradacji struktur pochodzenia, różnych zagrożeń, nie mogą pozostać w ich miejscu pierwotnym; badają historię wspólnoty chrześcijańskiej, gdyż w urządzeniu muzeum, w wyborze elementów

${ }^{11}$ Warto zauważyć, że ,,ani w Kodeksie Prawa Kanonicznego z 1917 r. ani w KPK z 1983 r. oraz w Kodeksie Kanonów Kościołów Wschodnich, nie mówi się wprost o muzeach kościelnych, aczkolwiek są tam jasne zalecenia, aby troszczyć się o dziedzictwo artystyczne i historyczne Kościoła". Pontificia Commissione per i Beni Culturali della Chiesa, Lettera circolare La funzione pastorale dei musei ecclesiastici (29 iunii 2001), nr 1.4, (dalej: La funzione pastorale dei musei ecclesiastici) w: Enchiridion dei Beni Culturali della Chiesa. Documenti ufficiali della Pontificia Commissione per i Beni Culturali della Chiesa, Edizioni Dehoniane, Bologna 2002, s. 464-526.

${ }_{12}$ Schema-tipo di regolamento delle biblioteche ecclesiastiche italiane Stowarzyszenia Włoskich Bibliotekarzy Kościelnych, zatwierdzony przez Stałą Radę Biskupią Konferencji Episkopatu Włoch na posiedzeniu w dniach 16-19 września 2002 r. zawiera następującą definicję biblioteki kościelnej: „,biblioteka kościelna jest to uporządkowany zbiór rękopisów, druków lub opracowań i innych środków, mający na celu przekazywanie tekstów i obrazów, będący w posiadaniu instytucji aprobowanych albo erygowanych w systemie kanonicznym". Associazione dei Bibliotecari Ecclesiastici Italiani, Schema-tipo di regolamento delle biblioteche ecclesiastiche italiane approvato dalla CEI, art. 1, nr 1, „Bollettino di informazione”, 22 (2002) z. 3, s. 10-19.

13 „Kościół katolicki na podstawie prawa wrodzonego, niezależnie od władzy świeckiej, może dobra doczesne nabywać, posiadać, zarządzać i alienować, dla osiągnięcia właściwych sobie celów”. Patrimonium historyczno-artystyczne Kościoła należy do kościelnych dóbr doczesnych. Por. kan. $1257 \S 1$.

${ }^{14}$ Trzeba dodać, że wyłączenie obiektów liturgicznych z kultu i umieszczenie ich w muzeum nie ma charakteru absolutnego, gdyż „należy zagwarantować prawnie i praktycznie ewentualne tymczasowe powtórne użycie dóbr muzealnych, bądź dla racji ściśle duszpasterskich i liturgicznych, bądź dla motywów kulturalnych i społecznych". La funzione pastorale dei musei ecclesiastici, nr 2.1.1. Celami dóbr doczesnych Kościoła są „organizowanie kultu Bożego, zapewnienie godziwego utrzymania duchowieństwa oraz innych pracowników kościelnych, prowadzenie dzieł apostolatu i miłości, zwłaszcza wobec biednych”. Kan. 1254 § 2; por. kan. 222 § 1. „Muzeum Archidiecezjalne z kolei gromadzi, zabezpiecza, konserwuje i eksponuje dzieła sztuki sakralnej, zbierane z terenu całej Archidiecezji po wycofaniu ich z kultu". III Powojenny Synod Archidiecezji Gnieźnieńskiej z okazji Millenium jej powstania, Gniezno 2001, st. 23 § 3, s. 82; por. kan. 1283.

${ }^{15}$ La funzione pastorale dei musei ecclesiastici, $\mathrm{nr}$ 2.2.1. 
i ich rozmieszczeniu muszą rekonstruować i ukazywać ewolucję czasową i przestrzenną wspólnoty chrześcijańskiej; podkreślają ciągłość historyczną wspólnoty chrześcijańskiej; konfrontują kulturę katolicką z przejawami innych kultur określonego terytorium ${ }^{16}$.

Innym istotnym celem museo ecclesiastico jest realizowanie duszpasterstwa poprzez pamiątki historyczne. Instytucja ta posiada przywilej bycia narzędziem wzrostu w wierze. Ma więc charakter pastoralny, potwierdzany przez charakter zbiorów zwykle przechowywanych w tych placówkach kościelnych. Rękodzieła te mimo swej różnorodności, odnoszą się do jedynego systemu kulturalnego i pomagają odtworzyć zmysł teologiczny, liturgiczny i pobożnościowy wspólnoty. $\mathrm{Z}$ tego względu przedmioty używane kiedyś w celach kultu Bożego, formacji wiernych i dzieł miłosierdzia, nie stają się zwyczajnie rzeczami martwymi, lecz co najwyżej nie są używane. Pozostają w nich nadal aspekty kulturowe, teologiczne, liturgiczne, historyczne i przede wszystkim formy artystyczne, które sprawiają, że te nieużywane przedmioty w dalszym ciągu zachowują swą funkcję duszpasterską. W takim kontekście muzeum kościelne świadczy o dorobku Kościoła na przestrzeni czasu, przez co spełnia swój duszpasterski obowiązek wobec historii i wobec piękna. Instytucja muzeum kościelnego pozwala poprzez dzieła sztuki, rozpoznać transitus Domini poprzez historię wspólnoty chrześcijańskiej.

Jako narzędzie duszpasterskie muzeum kościelne służy odkryciu i przeżyciu jeszcze raz świadectwa wiary minionych pokoleń poprzez widzialne dzieła. Muzeum pomaga także w zrozumieniu piękna odciśniętego w różnych formach w dziełach starożytnych i współczesnych. W ten sposób służy ukierunkowaniu serca, myśli i woli na Boga. Kruchość materiału, naturalne nieszczęścia, wrogie albo sprzyjające warunki historyczne, zmiany wrażliwości kulturalnej, reformy liturgiczne - to wszystko znajduje udokumentowanie w muzeach kościelnych. One pamiętają, poprzez zwyczajne czy wybitne dzieła minionej epoki, ukazują piękno tego, co zostało zachowane i ludzką moc twórczą połączoną z wiarą. Instytucje muzealne przyjmują ponadto funkcję magisterialną i katechetyczną, dostarczając perspektywy historycznej i estetycznego zadowolenia ${ }^{17}$.

Gdy idzie o typologię muzeów kościelnych, to trzeba powiedzieć, że nie ma wyczerpującej listy muzeów kościelnych. Istnieje jednak możliwość podania pewnych ogólnych kryteriów klasyfikacji tych instytucji.

Można dokonać podziału muzeów odwołując się do instytucji kościelnej, która jest ich właścicielem, albo która dała im początek. W ramach tego kryterium znajdują się: skarbce katedralne, jako najdawniejsze prawdziwie kościelne instytucje muzealne ${ }^{18}$. Te instytucje, $w$ bardzo wielu przypadkach istnieją do dziś, strzegąc drogocennych przedmiotów liturgicznych. W ciągu wieków do tych skarbców dołączano muzea katedralne, a w pewnych rejonach muzea Opera del Duomo mające luźniejszy związek z kultem, przechowujące i eksponujące dzieła sztuki i inne znaleziska pochodzące z katedry i jej sąsiedztwa.

${ }^{16}$ Por. tamże; por. kan. $1220 \S 2$.

${ }^{17}$ Por. La funzione pastorale dei musei ecclesiastici, nr 2.2.2.

18 „W (...) salach wystawowych [Muzeum Archidiecezjalne] udostępnia ponadto zasoby katedralnego skarbca". III Powojenny Synod Archidiecezji Gnieźnieńskiej, st. 23 § 3, s. 82. 
Istnieją także różne typy kolekcji z natury zwykle monograficzne (zbiory artystyczne, archeologiczne, naukowe), niektóre o starożytnej proweniencji, inne powstawały w niedawnych czasach. Zbiory te, które niekiedy stawały się własnością kościelną w przypadkowych okolicznościach, mają różne pochodzenie: od osób prywatnych, instytucji kościelnych, instytucji świeckich, innych instytucji ${ }^{19}$.

Po soborze watykańskim drugim zaczęto tworzyć muzea diecezjalne, aby zapobiegać niebezpieczeństwu rozproszenia dziedzictwa artystycznego diecezji. Miały one zwykle charakter wyraźnie kulturalny ${ }^{20}$. Powstawały także muzea parafialne $^{21}$, międzyparafialne, regionalne, monastyczne, konwentualne instytutów zakonnych (na przykład muzeum misyjne), konfraterni i innych instytucji kościelnych $^{22}$. Można też mówić o muzeach sanktuaryjnych. Według kan. 1234 § ,wota sztuki ludowej i dokumenty pobożności winny być przechowywane w sanktuariach lub w miejscach przyległych, i bezpiecznie strzeżone"23.

Innym kryterium podziału muzeów kościelnych są rodzaje zbiorów tam obecnych, które można podzielić na te użytkowane w liturgii i w nabożeństwach paraliturgicznych. Można je zgrupować w nastepujących kategoriach:

- dzieła sztuki (malarstwo, rzeźba, dekoracje, ryciny, druki, prace stolarstwa artystycznego);

- naczynia święte;

- meble;

- relikwiarze i wota;

- paramenty liturgiczne, tkaniny, koronki, hafty, stroje kościelne;

- instrumenty muzyczne;

- manuskrypty i księgi liturgiczne, księgi chóralne, partytury muzyczne, itd.

Do kategorii rękodzieła, które zwykle tworzą dziedzictwo muzeów kościelnych, dołącza się często inne materiały, które zwyczajnie przynależą do archiwów i bibliotek, takie jak: dencje)

- projekty architektoniczne i artystyczne (rysunki, modele, szkice, korespon-

${ }^{19}$ Por. La funzione pastorale dei musei ecclesiastici, nr 2.3.1.

${ }^{20}$ Zob. Sacra Congregatio pro Clericis, Litterae circulares de cura patrimonii historico-artistici Ecclesiae, ad praesides Conferentiarum Episcopalium Opera artis (11 aprilis 1971) (dalej: Opera artis), nr 6, „Acta Apostolicae Sedis”, 63 (1971) s. 315-317, tekst polski: Okólnik Kongregacji spraw Duchowieństwa skierowany do przewodniczacych Konferencji Biskupich a dotyczacy troski o zachowanie artystycznego i historycznego dziedzictwa Kościoła, „Posoborowe Prawodawstwo Kościelne”, t. IV, z. 1, Warszawa 1972, s. 112-119. Istnieją także muzea międzydiecezjalne. Por. tamże, nr 6.

${ }^{21}$ Por. Pierwszy Synod Diecezji Zamojsko-Lubaczowskiej 1996-2001, Zamość 2001, st. 192, s. 155; zob. A. Tokarzewski, Muzeum parafialne w Lubartowie, „Archiwa, Biblioteki i Muzea Kościelne", 79 (2003) s. 193-195.

${ }^{22}$ Por. La funzione pastorale dei musei ecclesiastici, nr 2.3.1; por. C. Chenis, Natura, kompetencje, 39 .

${ }^{23}$ Por. Statut Sanktuarium św. Michała Archanioła i bł. Bronisława Markiewicza w Miejscu Piastowym (4 czerwca 2007), nr 43, „Kronika Archidiecezji Przemyskiej”, 92 (2007) nr 2, s. 296; por. J. Dudziak, Prawno-kanoniczna koncepcja sanktuarium, „Tarnowskie Studia Teologiczne”, 9 (1983) s. 72. 
- dokumenty mające związek z rękodziełami (zapisy, testamenty, umowy, czynności prawne)

- księgi wspomnień o dziełach, dokumentacje zbiorów

- inne materiały związane w pewnym stopniu z dziedzictwem historyczno -artystycznym (przepisy, statuty, rejestry) dotyczące diecezji i parafii, instytutów życia konsekrowanego i stowarzyszeń życia apostolskiego, konfraterni i „dzieł pobożnych"24.

Ponadto muzeum kościelne musi troszczyć się o zachowanie pamięci o zwyczajach, tradycjach i obyczajach własnej wspólnoty kościelnej i społeczności świeckiej, szczególnie w tych narodach, w których przechowywanie rękodzieł i dokumentów nie jest jeszcze rozpowszechnione ${ }^{25}$.

Trzeba dodać, że muzeum kościelne gromadzi zbiory „uzyskane drogą darowizn, depozytów i zakupów"26. Normy Konferencji Episkopatu Polski w sprawach sztuki kościelnej postanawiają w tym względzie: „obiekty wycofane z bezpośredniego kultu lub dekoracji wnętrza kościelnego, należy umieścić w osobnych i zabezpieczonych pomieszczeniach, jako zaczątek kolekcji parafialnej lub klasztornej, albo oddać do Muzeum Diecezjalnego"27.

\section{Ustanawianie muzeów kościelnych}

Muzea kościelne są własnością instytucji aprobowanych albo erygowanych w systemie kanonicznym. Podlegają więc one władzy kościelnej, która je powołuje do istnienia i sprawuje nad nimi nadzór. Według okólnika La funzione pastorale dei musei ecclesiastici muzea kościelne sytuują się wśród narzędzi „w służbie

${ }^{24}$ Por. La funzione pastorale dei musei ecclesiastici, nr 2.3.2; por. Pontificia Commisione per i Beni Culturali della Chiesa, Lettera circolare Necessità urgenza dell'inventariazione e catalogazione dei beni culturali della Chiesa (8 dicembre 1999) (dalej: Necessità urgenza dell'inventariazione e catalogazione), nr 2.2, w: Enchiridion dei beni culturali della Chiesa. Documenti ufficiali della Pontificia Commissione per i Beni Culturali della Chiesa, Edizioni Dehoniane, Bologna 2002, s. 400-437.

${ }^{25}$ Por. La funzione pastorale dei musei ecclesiastici, nr 2.3.2; por. Statut muzeum diecezjalnego, w: Pierwszy Synod Diecezji Zamojsko-Lubaczowskiej 1996-2001, § 6, nr 2, § 7, Zamość 2001, s. 204-208.

${ }^{26}$ Statut muzeum diecezjalnego, $\S 6, \mathrm{nr} 1, \S 10, \mathrm{nr} 6$; Opera artis, $\mathrm{nr}$ 6; por. kan. 1269. „Nieużywane przedmioty artystyczne i zabytkowe [należące do danej kościelnej osoby prawnej] należy oddać w depozyt do Muzeum Archidiecezjalnego". III Powojenny Synod Archidiecezji Gnieźnieńskiej, st. 395 § 3, s. 235. „Ważniejsze naczynia liturgiczne oraz obrazy (...) o znacznej wartości artystycznej i historycznej (...) wycofane na stałe z użytku liturgicznego, winny być (...) przekazane do Muzeum Diecezjalnego w Zamościu”. Pierwszy Synod Diecezji Zamojsko-Lubaczowskiej, st. 39, s. 40. „Muzeum Diecezjalne im. Biskupa Stanisława Wojciecha Okoniewskiego istniejące w Pelplinie od roku 1928 gromadzi zabytki rzeźby, malarstwa i rzemiosła artystycznego (złotnictwo, kowalstwo i tkaniny). Część zabytków to zbiory własne, a część depozyty z różnych parafii”. Statuty I Synodu Diecezji Pelplińskiej, Pelplin 2001, st. 93, s. 32. „Zbiory muzealne są powiększane drogą depozytów parafialnych i darowizn osób prywatnych, a w szczególnych wypadkach drogą zakupu". Synod Archidiecezji Wrocławskiej 1985-1991, st. C, nr 5, Wrocław 1995, s. 365.

${ }^{27}$ Normy postępowania w sprawach sztuki kościelnej wydane przez Konferencję Episkopatu Polski (25 stycznia 1973), § 16, „Currenda”, 124 (1974) nr 9-10, s. 205-211. 
misji Kościoła", które trzeba umieścić w ramach duszpasterstwa diecezjalnego ${ }^{28}$. Kierowanie, normowanie i opieka nad tym wszystkim, co należy do kościelnych dóbr kultury w poszczególnych diecezjach i kościołach lokalnych, a także tworzenie muzeum diecezjalnego i innych muzeów kościelnych związanych z diecezją, należy do biskupa diecezjalnego, którego powinna wspierać stosowna komisja diecezjalna, względnie inny urząd do spraw sztuki kościelnej i dóbr kultury ${ }^{29}$.

Utworzenie ekspozycji muzealnych staje się koniecznością dla ochrony, opieki i waloryzacji dziedzictwa historycznego i artystycznego ${ }^{30}$. Faktycznie ,jeżeli zaś wspomniane dzieła zostaną uznane za nieprzydatne już więcej do kultu Bożego, to w żadnym wypadku nie mogą być przeznaczone do świeckiego użytku, lecz należy je umieścić $\mathrm{w}$ odpowiednim miejsca, to jest w muzeum diecezjalnym lub międzydiecezjalnym, do którego mieliby dostęp wszyscy pragnący je obejrzeć"31.

Muzeum kościelne musi być erygowane dekretem biskupim i powinno być wyposażone w statut i regulamin, które będą wskazywać na jego naturę i cele oraz strukturę i rozwiązania organizacyjne. Żadne nowe muzeum kościelne nie będzie mogło być urzeczywistnione przez podmioty kościelne, przez instytucje publiczne i prywatne, nawet jeśli całkowicie albo częściowo będzie sfinansowane przez nie, bez zgody właściwego biskupa diecezjalnego ${ }^{32}$.

Za muzea instytutów zakonnych i stowarzyszeń życia apostolskiego odpowiedzialni są, według prawa własnego, ich wyżsi przełożeni. Wykonują oni swoje zadania w tym zagadnieniu poprzez przełożonych lokalnych, w których domach zostały założone i funkcjonują muzea ${ }^{33}$. Trzeba dodać, że przepisy kościelne ustanowione w celu koordynacji, organizacji i zarządzania muzeami powinny być stosowane również $\mathrm{w}$ muzeach należących do instytutów zakonnych i stowarzyszeń życia apostolskiego, z uwzględnieniem norm prawa cywilnego i życia wewnętrznego członków instytutu utrzymującego muzeum ${ }^{34}$. W przypadku, gdy muzeum diecezjalne jest powierzone trosce instytutu zakonnego, należy przestrzegać dyspozycji przewidzianych w kan. $681^{35}$.

${ }^{28} \mathrm{Nr} 2.4$.

${ }^{29}$ Por. kan. $1257 \S 1 ; 1276 \S 2 ; 368 ; 381 \S 1 ; 394 \S 1$; por. La funzione pastorale dei musei ecclesiastici, nr 2.4; por. Opera artis, $\mathrm{nr} 4$.

${ }^{30}$ Por. PB, art. 100; por. kan. $1220 \S 2$; por. G. Menis, Muzea Kościoła, s. 82.

${ }^{31}$ Opera artis, nr 6.

${ }^{32}$ Por. La funzione pastorale dei musei ecclesiastici, $\mathrm{nr} 2.4$; por. kan. $1276 \S 2 ; 381 \S 1$. „Muzeum Diecezjalne w Zamościu, nazywane dalej Muzeum Diecezjalnym lub Muzeum, istnieje i działa w ramach Diecezji Zamojsko-Lubaczowskiej jako jeden z jej organów podlega Biskupowi Diecezjalnemu jako nadrzędnej i jedynej władzy”. Statut muzeum diecezjalnego, $\S 2$.

${ }^{33}$ Por. La funzione pastorale dei musei ecclesiastici, nr 2.4; por. kan. 620, 734.

${ }^{34}$ Por. La funzione pastorale dei musei ecclesiastici, $\mathrm{nr} 2.4$.

${ }^{35}$ Kan. $681 \S 1$. „Dzieła powierzane zakonnikom przez biskupa diecezjalnego podlegaja jego władzy i kierownictwu, z zachowaniem prawa przełożonych, zgodnie z kan. $678, \S \S 2$ i 3 . $\S 2$. W takich przypadkach biskup diecezjalny i kompetentny przełożony winni zawrzeć pisemną umowę, w której, obok innych spraw, należy wyraźnie i dokładnie określić to, co się odnosi do przedmiotu wykonywanego dzieła, przydzielania do niego zakonników i spraw materialnych"; por. La funzione pastorale dei musei ecclesiastici, nr 2.4. 
W tworzeniu muzeum, tam gdzie istnieje taka możliwość, należy utworzyć komitet, składający się z ekspertów, kierowanego przez dyrektora mianowanego przez biskupa ${ }^{36}$. Ma on zadbać, w porozumieniu $\mathrm{z}$ właściwymi władzami kościelnymi, o zorganizowanie pomieszczeń muzealnych, wybór materiałów, strategie ekspozycji, relacje z personelem, animowanie odwiedzających. Szczególnie będzie musiał poszukiwać źródeł dochodu, starając się o pozyskanie funduszy na działalność muzeum ${ }^{37}$.

\section{Organizacja muzeów kościelnych}

Aby muzea kościelne mogły funkcjonować i spełniać swoją rolę duszpasterską konieczna jest ich odpowiednia organizacja ${ }^{38}$.

Przede wszystkim museo ecclesiastico winno mieć własną siedzibę w budynku, najlepiej będącym własnością kościelną. Autorzy okólnika Funkcja pastoralna muzeów kościelnych zauważają, że w wielu wypadkach muzea znajdują się w gmachach o wielkiej wartości historyczno-architektonicznej, które same przez się identyfikują i wskazują na muzeum kościelne ${ }^{39}$.

Wydaje się, że muzeum parafialne będzie się często mieścić w domu parafialnym $^{40}$, a muzeum zakonne w części klasztoru, poza klauzurą ${ }^{41}$.

Organizacja przestrzeni muzealnej musi przestrzegać ściśle określonych kryteriów. Urządzenie muzeum musi odpowiadać ogólnemu projektowi opracowanemu przez właściwego w tej materii architekta, któremu winni pomagać odpowiedni specjaliści mający przygotowanie zarówno od strony technicznej (budynki i wyposażenie), jak i nauk humanistycznych (teologia, historia, dyscypliny artystyczne) $)^{42}$.

Warto dodać, że siedziba muzeum kościelnego powinna być jak najlepiej zorganizowana, aby była łatwo dostępna, bez powodowania zakłóceń, zarówno w odniesieniu do zwiedzających, jak i do pracowników muzealnych. Trzeba oprócz tego upewnić się, że zastosowano środki konieczne dla dostępu i możliwości zwiedzania osób niepełnosprawnych stosownie do wskazówek ustawodawstwa międzynarodowego lub państwowego ${ }^{43}$.

Redaktorzy listu okólnego La funzione pastorale dei musei ecclesiastici, proponują tytułem przykładu wzorcowy plan organizacji muzeum kościelnego

${ }^{36}$ Por. Opera artis, $\mathrm{nr} 4$. W przypadku muzeum parafialnego odpowiedzialnym będzie proboszcz (por. kan. 519, 532), muzeum zakonnego - przełożony lokalny (por. La funzione pastorale dei musei ecclesiastici, $\mathrm{nr}$ 2.4).

${ }^{37}$ Por. La funzione pastorale dei musei ecclesiastici, nr 2.4.

${ }^{38}$ Oczywiście stopień organizacji, jej adekwatność, będzie zależny od rodzaju i wielkości muzeum. Bardziej rozbudowana będzie organizacja w przypadku muzeów większych (np. muzeum diecezjalne), mniej skomplikowana w muzeach mniejszych (np. parafialnych).

${ }^{39} \mathrm{Nr} 3.1 .1$; zob. Opera artis, $\mathrm{nr} 6$.

${ }^{40}$ Por. kan. $533 \S 1$.

${ }^{41}$ Por. kan. $667 \S 1$.

${ }^{42}$ Por. La funzione pastorale dei musei ecclesiastici, nr 3.1.1.

${ }^{43}$ Por. tamże; por. Opera artis, nr 6. 
zwracając uwagę na następujące elementy jego organizacji44: właściwie urządzone wejście do muzeum z odpowiednią informacją, możliwość skorzystania z pomocy osób oprowadzających po muzeum (przewodnicy) 45 ; odpowiednie, logiczne, zgodnie z kryteriami muzeologicznymi, historycznymi i teologicznymi zaaranżowanie sal wystawowych, gdzie z łatwością można śledzić wieloaspektową historię Kościoła partykularnego, specyfikę instytutu zakonnego, sanktuarium albo $\mathrm{z}$ innego miejsca kościelnego ${ }^{46}$; gabloty odpowiednio oświetlone tak, aby nie zanikały kolory rękodzieł i przez to nie zakłócało się ich oglądanie, dokładnie objaśniające napisy w gablotach w dwóch lub trzech językach, sporządzone czytelnym pismem (wydrukowane) i umieszczone w odpowiednim miejscu ${ }^{47}$; sale wystaw okresowych dla podkreślenia szczególnych okazji (np. „mocne” okresy liturgiczne, święta tytularne i patronalne, okoliczności państwowe, zjazdy naukowe $)^{48}$; sala dydaktyczna przeznaczona w szczególności dla studentów, pracowników duszpasterstwa i katechetów ${ }^{49}$; w miarę możliwości należycie wyposażona sala formacji kulturalnej dla kształcenia i doszkalania pracowników, wolontariuszy, badaczy, studentów ${ }^{50}$; biblioteka specjalistyczna wyposażona w literaturę fachową, umożliwiająca konsultację przynajmniej publikacji dotyczących historii i kultury lokalnej i w miarę możności posiadająca wideotekę albo inne nośniki multimedialne ${ }^{51}$; archiwum bieżące zawierające rejestry nabytków i wypożyczeń muzealiów, okresowo aktualizowane inwentarze i katalogi ${ }^{52}$, dokumenty czynności prawnych i administracyjnych, wykazy fotografii i grafik oraz archiwum historyczne (różne od zwyczajnego archiwum historycznego Kościoła lokalnego, zakonu lub innej instytucji kościelnej) zawierające co najmniej kopie wszystkich materiałów potrzebnych do udokumentowania historii poszczególnych eksponatów istniejących w muzeum ${ }^{53}$; wyjście $\mathrm{z}$ muzeum, w miarę możności różne od wejścia nie tylko, aby uniknąć bałaganu wśród odwiedzających muzeum (szcze-

${ }^{44}$ Będzie się to odnosiło głównie do większych muzeów, ale pewne elementy mogą, a nawet muszą występować także w mniejszych placówkach muzealnych.

${ }^{45}$ Por. La funzione pastorale dei musei ecclesiastici, nr 3.1.2.

${ }^{46} \mathrm{~W}$ dużych muzeach warto przewidzieć w salach miejsca, gdzie można się zatrzymać, aby ułatwić zwiedzającym kontemplację wystawionych dzieł, zwłaszcza tych bardziej znaczących. Por. La funzione pastorale dei musei ecclesiastici, nr 3.1.3; zob. Necessità urgenza dell'inventariazione e catalogazione, Introduzione.

${ }^{47}$ Por. La funzione pastorale dei musei ecclesiastici, nr 3.1.4.

${ }^{48}$ Por. tamże, nr 3.1.5; por. Statut muzeum diecezjalnego, $\S 6$, nr 5.

${ }^{49}$ Por. La funzione pastorale dei musei ecclesiastici, nr 3.1.6; por. Statut muzeum diecezjalnego, $\S 6, \mathrm{nr} 4$.

${ }^{50}$ Por. La funzione pastorale dei musei ecclesiastici, nr 3.1.7; por. Statut muzeum diecezjalnego, $\S 6, \mathrm{nr} 4$.

${ }^{51}$ Por. La funzione pastorale dei musei ecclesiastici, nr 3.1.8; por. Statut muzeum diecezjalnego, $\S 6, \mathrm{nr} 7$.

${ }^{52}$ Por. kan. 1283, nr 2.

${ }^{53}$ Por. La funzione pastorale dei musei ecclesiastici, nr 3.1.9; por. Statut muzeum diecezjalnego, $\S 6, \mathrm{nr} 7$. Zasady korzystania $\mathrm{z}$ archiwum bieżącego i historycznego przez pracowników muzeum i konsultacji dokumentów przez badaczy, muszą być właściwie określone w przepisach partykularnych. Por. La funzione pastorale dei musei ecclesiastici, nr 3.1.9. 
gólnie w muzeach o większym znaczeniu, gdzie przychodzi bardzo dużo zwiedzających), ale przede wszystkim po to, aby umożliwić pełne wykorzystanie proponowanej trasy zwiedzania ${ }^{54}$; miejsce posiłku (restauracja) umożliwiające przedłużenie pobytu w muzeum odwiedzających i badaczy ${ }^{55}$; biura pracowników (gabinet dyrektora i sekretariat) ${ }^{56}$; sale magazynowe (przestrzenie magazynowe) gdzie przechowywane są niewystawiane dzieła $^{57}$; pracownia konserwatorska ${ }^{58}$; systemy zabezpieczeń: instalacja elektryczna, przeciwpożarowa, alarmowa, klimatyzacja ${ }^{59}$; dozór muzeum odnoszący się nie tylko w sensie ogólnym do ochrony pomieszczeń muzealnych, ale także do obiegu dzieł wewnątrz samego muzeum i na zewnątrz (wypożyczanie) ${ }^{60}$; odpowiednie zarządzanie instytucją muzealną, na które składają się: zapewnienie źródeł finansowania ${ }^{61}$, prowadzenie rozliczeń finansowych, ubezpieczenia pracowników i zbiorów, promocja muzeum w mediach kościelnych i świeckich, publikacje muzealne ${ }^{62}$, zabezpieczenie prawne muzeum na forum kościelnym i świeckim, kwestie podatkowe, umowy o pracę, zapewnienie podstaw prawnych wolontariuszy ${ }^{63}$.

\section{Pracownicy muzeów kościelnych i ich formacja}

Każde muzeum proporcjonalnie do swojej wielkości, znaczenia i możliwości finansowych, potrzebuje określonych pracowników. Muzeum obowiązkowo ma kierować dyrektor, który powinien mieć odpowiednie kompetencje (naukowe i organizacyjne) oraz odznaczać się zaangażowaniem w sprawach muzeum ${ }^{64}$. Może nim być zarówno duchowny, osoba konsekrowana jak i wierny świecki. Dyrektora muzeum mianuje biskup diecezjalny ${ }^{65}$. Reprezentuje on tę instytucję na zewnątrz i odpowiada za całość prac przed biskupem diecezjalnym.

Według Statutu muzeum diecezjalnego, dyrektor prowadzi nadzór nad zbiorami i majątkiem muzeum, kieruje sprawami naukowo-badawczymi, organizacyjnymi i administracyjnymi, wydaje zarządzenia wewnętrzne, powołuje specjalistów w sprawach szczególnie ważnych dla zabytków i ich konserwacji, prowadzi inwentaryzację zabytków znajdujących się w kościołach, kaplicach i plebaniach na terenie diecezji, prowadzi zakupy obiektów muzealnych, zwłaszcza takich, które mają ważne znaczenie dla diecezji, wyznacza eksponaty na wystawy i do

\footnotetext{
${ }^{54}$ Por. La funzione pastorale dei musei ecclesiastici, nr 3.1.10.

${ }^{55}$ Por. tamże, nr 3.1.11.

${ }^{56}$ Por. tamże, nr 3.1.12.

${ }^{57}$ Por. tamże, nr 3.1.13.

${ }^{58}$ Por. tamże, nr 3.1.14; por. Statut muzeum diecezjalnego, $\S 10, \mathrm{nr} 4,7 ; \S 13, \mathrm{nr} 2 ; \S 14, \mathrm{nr} 3$.

${ }^{59}$ Por. La funzione pastorale dei musei ecclesiastici, $\mathrm{nr} 3.2 .1$

${ }^{60}$ Por. tamże, nr 3.2.2.

${ }^{61}$ Zob. Statut muzeum diecezjalnego, $\S 5, \S 10, \mathrm{nr} 10$.

${ }^{62}$ Por. tamże, $\S 6$, nr 6.

${ }^{63}$ Por. La funzione pastorale dei musei ecclesiastici, nr 3.3.

${ }^{64}$ Por. tamże, nr 3.4. W małych muzeach funkcję dyrektora będzie pełnił proboszcz, czy przełożony domu zakonnego.

${ }^{65}$ Por. La funzione pastorale dei musei ecclesiastici, nr 2.4; 5.3. Statut muzeum diecezjalnego, $\S$ 9; Synod Archidiecezji Wroctawskiej, st. C, nr 3, s. 365.
} 
konserwacji, decyduje o udostępnianiu eksponatów znajdujących się w magazynach, opracowuje projekt budżetu muzeum i przedkłada go biskupowi diecezjalnemu do zatwierdzenia, przedstawia biskupowi diecezjalnemu plany rzeczowe oraz wnioski i sprawozdania finansowe, za zgodą biskupa diecezjalnego zatrudnia i zwalnia pracowników muzeum oraz ustala zakres ich obowiązków, składa biskupowi diecezjalnemu coroczne sprawozdania z całokształtu działalności muzeum $^{66}$. Autorzy okólnika Funkcja pastoralna muzeów kościelnych jako ważne zadanie dyrektora uznają obowiązek poszukania źródeł finansowania muzeum ${ }^{67}$.

W miarę możliwości dyrektor winien być wspomagany przez komitet składający się z ekspertów (albo przynajmniej przez indywidualnych specjalistów) ${ }^{68}$. Według Statutu muzeum diecezjalnego pomocą dyrektorowi ma służyć Rada Muzealna, jako organ doradczy i opiniodawczy. Jej członków powołuje biskup diecezjalny na wniosek dyrektora muzeum. W jej skład wchodzą: dyrektor i kustosz, konserwator diecezjalny, kierownik pracowni konserwatorskiej oraz historyk sztuki i artysta plastyk. Radę Muzealną zwołuje i przewodniczy jej biskup diecezjalny. Posiedzenia odbywają się raz w roku, a w miarę potrzeby częściej. Przebieg obrad powinien być zaprotokołowany przez sekretarza. Do zadań Rady Muzealnej należy opiniowanie $\mathrm{i}$ wnioskowanie w sprawach związanych z całokształtem działalności muzeum, a w szczególności: ocena ogólnej działalności muzeum, składanie wniosków dotyczących usprawnienia jego działalności, omawianie metod gromadzenia zbiorów i ich konserwacji, ekspozycji i działalności upowszechniającej oraz wydawniczej, opracowanie programu badań naukowych ${ }^{69}$.

Okólnik Opera artis przypomina, że biskupi (...) winni nieustannie czuwać, by zmiany, jakie w miejscach świętych mają być wprowadzone w związku z reformą liturgiczną, dokonywane były z zachowaniem wszelkiej ostrożności i zawsze zgodnie z normami odnowy liturgicznej, a ich realizacja była dokonywana po zasięgnięciu opinii Komisji do Spraw Sztuki Sakralnej, Komisji do Spraw Liturgii oraz - jeżeli trzeba - również Komisji do Spraw Muzyki Sakralnej oraz rady rzeczoznawców"70. Można więc pośrednio wnioskować, że także dyrektorowi muzeum diecezjalnego będą służyć pomocą wspomniane: Komisja do Spraw Sztuki Sakralnej, Komisja do Spraw Liturgii oraz - jeżeli trzeba - również Komisji do Spraw Muzyki Sakralnej oraz rada rzeczoznawców. Autorzy Opera artis mówią bowiem, że ,jeżeli zajdzie potrzeba dostosowania dzieł sztuki i skarbów przekazanych przez poprzednie wieki do nowych przepisów liturgicznych, biskupi winni zatroszczyć się, by to nie działo się bez prawdziwej potrzeby i ze szkodą dla tych dzieł. Ponadto zawsze należy zachować normy i kryteria podane w punkcie 4. Jeżeli zaś wspomniane dzieła zostaną uznane za nieprzydatne już więcej do kultu Bożego, to w żadnym wypadku nie mogą być przeznaczone do świeckiego użytku, lecz należy je umieścić w odpowiednim miejsca, to jest w muzeum die-

\footnotetext{
${ }^{66} \S 10-12$.

${ }^{67} \mathrm{Nr} 2.4$.

${ }^{68}$ Por. La funzione pastorale dei musei ecclesiastici, $\mathrm{nr} 2.4 ; 3.4 ; 5.3$.

${ }^{69} \S 13-14$.

${ }^{70} \mathrm{Nr} 4$.
} 
cezjalnym lub międzydiecezjalnym, do którego mieliby dostęp wszyscy pragnący je obejrzeć" 71 .

Tam, gdzie okaże się przydatne, można zatrudnić sekretarkę, np. dla administracji ekonomicznej, itpp ${ }^{72}$ a także odpowiednich przewodników oprowadzających zwiedzających po ekspozycjach muzealnych. Winni oni posiadać kompetencje do oprowadzania różnych kategorii osób odwiedzających muzeum ${ }^{73}$.

Na podstawie przepisów zawartych w dokumentach kościelnych można wymienić innych pracowników muzeum: osobę odpowiedzialną za prowadzenie podręcznej biblioteki muzealnej ${ }^{74}$, archiwum muzealnego ${ }^{75}$, pracowników obsługujących wejście do muzeum (szatnia, informacja) ${ }^{76}$, pracowników ochrony (dozoru) $)^{77}$.

Niewątpliwie nie wszyscy wymieni pracownicy są nieodzowni we wszystkich muzeach. Będzie to zależało od wielkości instytucji muzealnej, jak i od możliwości finansowych. Wielu pracujących w różnych kategoriach muzeów kościelnych będzie to czyniło na zasadzie wolontariatu, co nie wyklucza ich kompetencji w sprawach, których się podejmują ${ }^{78}$. Są to najczęściej emeryci, młodzi poszukujący swojej pierwszej pracy, studenci oraz wszyscy, którzy z racji swojego zawodu związani są z działalnością muzealną i zamierzają poświęcić nieodpłatnie muzeum kościelnemu część swojego wolnego czasu (pomoc doraźna) ${ }^{79}$.

Muzeum jako centrum artystyczno-historyczne, może odgrywać istotną rolę kulturalną, jeśli rozwija działalność dotyczącą informacji historycznej i wychowania estetycznego w ramach planu duszpasterskiego. Aby osiągnąć ten cel musi przeprowadzać szkolenia swoich pracowników. Trzeba dodać, że warunkiem zatrudnienia $\mathrm{w}$ muzeum na konkretne stanowiska jest posiadanie przez określone osoby stosownego przygotowania do wykonywania określonych zadań w muzeum.

${ }^{71} \mathrm{Nr} 6$. Wspomniany w przytoczonym passusie punkt 4 mówi o konieczności zasięgnięcia opinii Komisji do Spraw Sztuki Sakralnej, Komisji do Spraw Liturgii oraz - jeżeli trzeba - również Komisji do Spraw Muzyki Sakralnej oraz rady rzeczoznawców w sprawie dzieł sztuki.

${ }^{72}$ Por. La funzione pastorale dei musei ecclesiastici, nr 3.4; 3.1.12.

${ }^{73}$ Por. tamże, nr 3.4.

${ }^{74}$ Zob. tamże, nr 3.1.8; Statut muzeum diecezjalnego, § 6, nr 7.

${ }^{75}$ Por. La funzione pastorale dei musei ecclesiastici, $\mathrm{nr} 3.1 .9$; Statut muzeum diecezjalnego, $\S$ $6, \mathrm{nr} 7$.

${ }^{76}$ Por. La funzione pastorale dei musei ecclesiastici, nr 3.1.2.

${ }^{77}$ Por. tamże 3.2.2. Na pracowników dozoru wskazuje także jedno z podstawowych zadań muzeów: strzeżenie kościelnego dziedzictwa historyczno-artystycznego. „Do tego dziedzictwa należą na pierwszym miejscu wszystkie dzieła sztuki z przeszłości, które trzeba strzec i konserwować. Te zaś, które przestały służyć własnemu celowi, powinny być umieszczone w muzeach lub innych miejscach, aby mogły być oglądane". PB, art. 100.

${ }^{78}$ Por. La funzione pastorale dei musei ecclesiastici, nr 5.3. „W kontekście podejmowania obowiązków kościelnych wynurza się doniosłość i pożytek współodpowiedzialności wolontariuszy laików właściwie przygotowanych w zakresie różnych aspektów organizacyjnych muzeum. Zresztą, w wielu wypadkach muzea kościelne, zwłaszcza jeśli są małe, zwykle są zarządzane przez osoby, które realizują tę służbę nieodpłatnie i dobrowolnie w duchu wiary i świadectwa". Tamże.

${ }^{79}$ Por. La funzione pastorale dei musei ecclesiastici, nr 5.3. 
La funzione pastorale dei musei ecclesiastici mocno akcentuje konieczność formacji pracowników muzealnych, poprzez zaznajamianie ich ze źródłami ustawodawstwa powszechnego i partykularnego w zakresie cywilnym i kościelnym. Formacja ma odbywać się w trzech skoordynowanych sektorach: informacja historyczna, wychowanie estetyczne, wykładnia duchowa ${ }^{80}$.

Szkolenie powinno obejmować zróżnicowane zajęcia, zwracając szczególną uwagę na następujące kwestie: historia Kościoła powszechnego i lokalnego; historia tradycji ludowych; hagiografia i duchowość; ikonografia i ikonologia; historia sztuki i architektury kościelnej; historia instytutów życia konsekrowanego i ich obecności na określonym terytorium; historia stowarzyszeń katolickich, konfraterni, ruchów związanych z opieką społeczną, instytucji kulturalnych. W związku z tym należy organizować kursy, seminaria naukowe, konferencje, debaty, cykle wykładów, w celu umożliwienia kształcenia podstawowego, specjalizacji i kształcenia ustawicznego ${ }^{81}$.

W odniesieniu do podmiotów odpowiedzialnych za kościelne muzeum, powinno odbywać się także specjalistyczne szkolenia. Oprócz tematyk wspomnianych wyżej, trzeba przewidzieć kształcenie odnoszące się do organizacji muzeów, administracji, umiejętności dydaktycznych, dozoru dóbr muzealnych, konserwacji rękodzieł, obowiązującego ustawodawstwa (w materii opieki, podatków, relacji z innymi instytucjami). Ewentualne biuletyny diecezjalne albo inne publikacje będą mogły natomiast aktualizować informacje przeznaczone dla pracowników muzeów kościelnych ${ }^{82}$.

Trzeba zauważyć, że w formacji odpowiedzialnych za muzea kościelne podkreśla się nie tylko profesjonalne przygotowanie ekspertów, ale raczej zagadnienie wprowadzenia ich w specyfikę kościelną. Powinni oni umieszczać dziedzictwo historyczno-artystyczne w odpowiednim kontekście katechetycznym, kultycznym, kulturalnym, charytatywnym, aby korzystanie z tych dóbr nie zostało zredukowane do aspektu czysto estetycznego, ale stało się duszpasterskim narzędziem poprzez uniwersalny język sztuki chrześcijańskiej ${ }^{83}$.

Obok zagadnienia ochrony, waloryzacji dziedzictwa historyczno-artystycznego Kościoła i kwestii muzeów kościelnych, zasadnicze znaczenie ma jednak formacja duchowieństwa i osób konsekrowanych. Kandydaci do kapłaństwa i do życia zakonnego powinni być tak kształtowani, aby potrafili doceniać dziedzictwo kulturalne Kościoła w perspektywie promocji kultury i ewangelizacji. Zazwyczaj kapłani pracujący w duszpasterstwie są faktycznie także odpowiedzialni za strzeżenie fabrica Ecclesiae, na którą składają się architektura i zabytki rękodzieła. Stąd w formacji seminaryjnej należy organizować kursy, na których w sposób gruntowny i systematyczny przedstawiać się będzie historię i początki sztuki sakralnej, archeologię chrześcijańską, archiwistykę i bibliotekarstwo ${ }^{84}$. Jest także

${ }^{80} \mathrm{Nr}$ 5.1.3.

${ }^{81}$ Por. La funzione pastorale dei musei ecclesiastici, nr 5.1.4.

${ }^{82}$ Por. tamże.

${ }^{83}$ Por. tamże, nr 5.2.2; por. Partyka, Funkcja duszpasterska muzeum archidiecezjalnego, s. 139.

${ }^{84}$ Por. Pontificia Commissione per i Beni Culturali della Chiesa, La formazione dei futuri presbiteri all'attenzione verso $i$ beni culturali della Chiesa (Ai vescovi diocesani) (15 ottobre 1992) 
pożądane, aby alumni uczestniczyli w różnych kursach filozoficznych i teologicznych podejmujących zagadnienia sztuki, estetyki, bibliotek, archiwów, muzeów ${ }^{85}$.

Bardzo przydatne jest publikowanie odpowiednich podręczników, które przedstawiałyby podstawowe wiadomości dotyczące złożonych zagadnień prawnych, liturgicznych, estetycznych, duszpasterskich i pomocy technicznych związanych z tworzeniem, konserwacją, renowacją, zarządzaniem i odpowiedzialnością w odniesieniu do dziedzictwa kulturowego Kościoła i roli, jaką w przyszłości będzie odgrywał kapłan ${ }^{86}$.

Odnośnie do formacji duchownych w relacji do patrimonium historyczno-artystycznego Kościoła, to redaktorzy listu okólnego na temat funkcji pastoralnej muzeów kościelnych proponują, aby organizować specjalne kursy dla księży w celu podniesienia świadomości organizacji i zarządzania muzeami kościelnymi oraz zachowania dziedzictwa kulturowego Kościoła ${ }^{87}$. Wspomniane kursy moga dotyczyć następujących kwestii: organizacji i dowartościowania muzeum diecezjalnego, utworzenia parafialnego lub lokalnego zbioru muzealnego, integracji muzeum diecezjalnego $\mathrm{z}$ określonym terytorium, animacji duszpasterskiej poprzez kościelne dziedzictwo historyczno-artystyczne, relacji z organami władzy cywilnej, kwestii administracji muzealnej itd. ${ }^{88}$.

Osobnym szkoleniem powinna być objęta kadra kierownicza (księża albo świeccy), którzy będą odpowiedzialni za muzea w diecezji. Powinni oni brać udział $\mathrm{w}$ specjalistycznych kursach organizowanych $\mathrm{w}$ diecezji, ewentualnie przez Konferencję Biskupią Regionalną lub Narodową, a także przez instytucje cywilne, czy centra akademickie ${ }^{89}$.

Ponadto świeccy mający podjąć się obowiązków w muzeach kościelnych oprócz specjalistycznych szkoleń i kursów, mogliby zdobywać przygotowanie ogólne przy kościelnych ośrodkach naukowych (uniwersytety, akademie, fakultety papieskie, wyższe instytuty wiedzy religijnych ${ }^{90}$.

\section{Zakończenie}

Działalność zbawcza Kościoła w wielu kulturach świata dała bodziec do tworzenia dóbr artystycznych, które wraz z upływem czasu nabywają wartości historycznej. Wiele z nich na skutek rozmaitych czynników zostaje wyłączonych

(dalej cyt.: La formazione dei futuri presbiteri), nr 22, „Notitiae”, 28 (1992) s. 714-731.

${ }^{85}$ Por. La funzione pastorale dei musei ecclesiastici, nr 5.2.1; 5.2.3.

${ }^{86}$ Por. La formazione dei futuri presbiteri, $\mathrm{nr} 23$; por. $\mathrm{nr} 12$. Ważną formą przygotowania przyszłych duszpasterzy do doceniania dóbr kultury kościelnej są: spotkania z artystami i krytykami sztuki, uczestniczenie w wybranych imprezach artystycznych o szczególnym znaczeniu, znajomość i wizyta w ewentualnych instytucjach diecezjalnych tyczących się kultury (muzea diecezjalne, archiwa, biblioteki), zwiedzanie najważniejszych zabytków sakralnych i świeckich istniejących w diecezji. Por. La formazione dei futuri presbiteri, nr 24.

${ }^{87}$ Por. La funzione pastorale dei musei ecclesiastici, nr 5.2.1.

${ }^{88}$ Por. tamże, nr 5.2.3.

${ }^{89}$ Por. tamże, nr 5.2.3; por. M. Leszczyński, Funkcja pastoralna muzeów kościelnych (Omówienie dokumentu Stolicy Apostolskiej), „Archiwa, Biblioteki i Muzea Kościelne”, 79 (2003) s. 149.

${ }^{90}$ Por. La funzione pastorale dei musei ecclesiastici, nr 5.2.3; zob. kan. $231 \S 1$. 
z użytku liturgicznego i kultu, w konsekwencji czego powstaje konieczność odpowiedniego ich przechowywania i konserwowania, aby przekazać przyszłym pokoleniom świadectwo o procesach inkulturacji wiary oraz umożliwić ich oglądanie w muzeach lub innych odpowiednich miejscach. Dziedzictwo artystyczno-historyczne Kościoła oraz muzea kościelne, jako należące do dóbr doczesnych, mają wymiar jurydyczny. Stąd kompetentna władza kościelna reguluje na płaszczyźnie prawnej sprawę ochrony dóbr artystycznych o wartości zabytkowej.

Kościelne dziedzictwo artystyczno-historyczne jest przechowywane w muzeach kościelnych, czyli instytucjach utworzonych w celu gromadzenia, zabezpieczenia przed zniszczeniem i zapewnienia fachowej konserwacji oraz prezentacji obiektów sakralnych (nieużywanych w kulcie), dla realizacji celów Kościoła, będących w posiadaniu instytucji aprobowanych albo erygowanych w systemie kanonicznym.

Istotną misją muzeum kościelnego jest służba w odkrywaniu i przeżywaniu świadectwa wiary minionych pokoleń poprzez widzialne dzieła.

Choć nie ma wyczerpującej typologii muzeów kościelnych, to jednak można dokonać ich klasyfikacji bądź odwołując się do instytucji kościelnej, która jest ich właścicielem, albo która dała początek muzeum, bądź na podstawie zbiorów obecnych w musei ecclesiastici.

Kierowanie, normowanie i opieka nad tym wszystkim, co należy do kościelnych dóbr kultury w poszczególnych diecezjach i kościołach lokalnych, a także tworzenie muzeum diecezjalnego i innych muzeów kościelnych związanych z diecezją, należy do biskupa diecezjalnego, którego powinna wspierać stosowna Komisja Diecezjalna, względnie inny urząd do spraw sztuki kościelnej i dóbr kultury.

Muzeum kościelne adekwatnie do swej wielkości i rangi powinno mieć odpowiednią organizację, na którą składają się: siedziba muzeum, zorganizowana przestrzeń muzealna według ściśle określonych kryteriów, kompetentni pracownicy muzealni $\mathrm{z}$ dyrektorem na czele.

Każde muzeum proporcjonalnie do swojej wielkości, znaczenia i możliwości finansowych, potrzebuje określonych pracowników, który powinni posiadać formację podstawową i specjalistyczną oraz uczestniczyć w kształceniu ustawicznym.

słowa kluczowe: muzeum, muzeum kościelne, muzeum diecezjalne, wystawy muzealne 


\section{BIBLIOGRAFIA}

\section{Źródła}

Associazione dei Bibliotecari Ecclesiastici Italiani, Schema-tipo di regolamento delle biblioteche ecclesiastiche italiane approvato dalla CEI, „Bollettino di informazione”, (2002) z. 3, s. 10-19.

Concilium Oecumenicum Vaticanum II, Constitutio pastoralis de Ecclesia in mundo huius temporis Gaudium et spes (7 Decembris 1965), „Acta Apostolicae Sedis”, 58 (1966) s. 1025-1115, tekst polski: Sobór Watykański II, Konstytucja duszpasterska o Kościele w świecie współczesnym Gaudium et spes, w: Sobór Watykański II. Konstytucje, dekrety, deklaracje. Tekst polski. Nowe tłumaczenie, Poznań 2002, s. 526-606.

III Powojenny Synod Archidiecezji Gnieźnieńskiej z okazji Millenium jej powstania, Gniezno 2001.

Ioannes Paulus P.P. II, Adhortatio Apostolica Post-Synodalis Ecclesia in Europa (28 Iunii 2003), „Acta Apostolicae Sedis”, 95 (2003), s. 649-719, tekst polski: „L'Osservatore Romano" wydanie polskie, 24 (2003), nr 7-8, s. 4-39.

Joannes Paulus P.P. II, Constitutio Apostolica Pastor Bonus, (28 iulii 1988), „Acta Apostolicae Sedis" 80 (1988), s. 841-912.

Normy postępowania w sprawach sztuki kościelnej wydane przez Konferencję Episkopatu Polski (25 stycznia 1973), „Currenda”, 124 (1974) nr 9-10, s. 205-211.

Pierwszy Synod Diecezji Zamojsko-Lubaczowskiej 1996-2001, Zamość 2001.

Pontifi cia Commisione per i Beni Culturali della Chiesa, Lettera circolare Necessità urgenza dell'inventariazione e catalogazione dei beni culturali della Chiesa ( 8 dicembre 1999), w: Enchiridion dei beni culturali della Chiesa. Documenti uffi ciali della Pontifi cia Commissione per i Beni Culturali della Chiesa, Edizioni Dehoniane, Bologna 2002, s. 400-437.

Pontificia Commissione per i Beni Culturali della Chiesa, La formazione dei futuri presbiteri all'attenzione verso i beni culturali della Chiesa (Ai vescovi diocesani) (15 ottobre 1992), „Notitiae”, 28 (1992) s. 714-731.

Pontificia Commissione per i Beni Culturali della Chiesa, Lettera circolare La funzione pastorale dei musei ecclesiastici (29 iunii 2001), [w:] Enchiridion dei Beni Culturali della Chiesa. Documenti ufficiali della Pontificia Commissione per i Beni Culturali della Chiesa, Edizioni Dehoniane, Bologna 2002, s. 464-526.

Pontificia Commissione per i Beni Culturali della Chiesa, Presentatione della Pontificia Commissione, Città del Vaticano 2004, tekst polski: Prezentacja Papieskiej Komisji do spraw Kościelnych Dóbr Kultury, „Biuletyn kościelnych dóbr kultury”, 1 (2005), s. $92-120$.

Sacra Congregatio pro Clericis, Litterae circulares de cura patrimonii historico-artistici Ecclesiae, ad praesides Conferentiarum Episcopalium Opera artis (11 aprilis 1971), „Acta Apostolicae Sedis”, 63 (1971), s. 315-317, tekst polski: Okólnik Kongregacji spraw Duchowieństwa skierowany do przewodniczących Konferencji Biskupich a dotyczący troski o zachowanie artystycznego i historycznego dziedzictwa Kościoła, „Posoborowe Prawodawstwo Kościelne”, t. 4, z. 1, Warszawa 1972, s. 112-119.

Statut Muzeum Diecezjalnego uchwalony przez Konferencję Episkopatu Polski (18 listopada 1976), „Currenda”, 127 (1977), nr 5-8, s. 1698-170.

Statut Sanktuarium św. Michała Archanioła i bł. Bronisława Markiewicza w Miejscu Piastowym (4 czerwca 2007), „Kronika Archidiecezji Przemyskiej”, 92 (2007) nr 2, s. 289-297.

Statuty I Synodu Diecezji Pelplińskiej, Pelplin 2001.

Synod Archidiecezji Wrocławskiej 1985-1991, Wrocław 1995. 


\section{Opracowania}

Chenis C., Natura, kompetencje, organizacja i działalność Papieskiej Komisji ds. Kościelnych Dóbr Kultury, „Biuletyn kościelnych dóbr kultury”, 1 (2005) s. 18-72.

Dudziak J., Prawno-kanoniczna koncepcja sanktuarium, „Tarnowskie Studia Teologiczne", 9 (1983) s. 60-73.

Leszczyński M., Funkcja pastoralna muzeów kościelnych (Omówienie dokumentu Stolicy Apostolskiej), „Archiwa, Biblioteki i Muzea Kościelne”, 79 (2003) s. 147-150.

Mały słownik terminów plastycznych, red. K. Zwolińska, Z. Malicki, Warszawa 1990.

Menis G., Muzea Kościoła, „Communio”, wersja polska, 16 (1996) z. 6, s. 89-97.

Partyka W., Funkcja duszpasterska muzeum archidiecezjalnego im. bł. Józefa Sebastiana Pelczara, biskupa w Przemyślu, „Archiwa, Biblioteki i Muzea Kościelne”, 79 (2003) s. $137-145$.

Skrzydlewska B., Historia i funkcjonowanie muzeów kościelnych, „Archiwa, Biblioteki i Muzea Kościelne", 79 (2003), s. 183-188.

Skrzydlewska B., Muzea religijne, w: Encyklopedia Katolicka, red. E. Gigilewicz, t. 13, Lublin 2009, k. 539-542.

Skrzydlewska B., Ochrona zabytków sztuki na podstawie dokumentów kościelnych, „Archiwa, Biblioteki i Muzea Kościelne”, 67 (1997) s. 33-40.

Słownik wyrazów obcych. Wydanie nowe, red. E. Sobol, Warszawa 1991.

Tokarzewski A. Muzeum parafialne w Lubartowie, „Archiwa, Biblioteki i Muzea Kościelne", 79 (2003) s. 193-195.

\section{CANONICAL INSTITUTION OF CHURCH MUSEUM}

\section{Summary}

This article presents the problems of the church museum in the context of the canon law. First, a concept, objectives and types of church museums are presented. Next, the issue of the church museum establishment is depicted. Much attention has been given to the organisation of such institutions. The final part of the presentation concerns employees of church museums and their formation, both primary and specialist as well as permanent.

Key words: museum, church museum, diocesan museum, museum exhibition, organised collection of resources, library resources, book collection, art and cultural heritage 